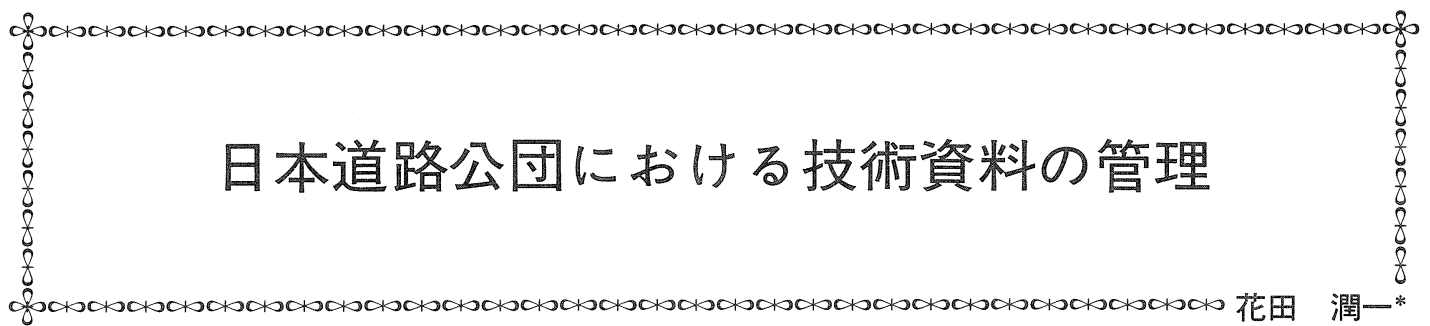

\title{
Management of technical data in Nihon Doro Kodan
}

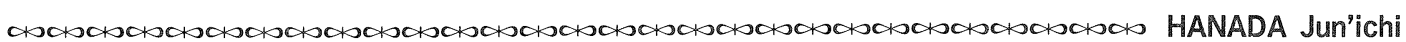

［著者抄録］日本道路公団では，事業の遂行に伴って発生する各種技術関係資料を，以後の 建設や, 管理業務などに有効利用するため, 昭和 43 年試験所に技術資料センターを設け, 20 年 以上にわたり，技術関係資料の収集・管理・提供業務を行ってきている。試験所では，資料の 検索や提供業務を迅速に行うため, 電算機を利用したシステム化を図り, 現在, 業務の成果品 としての技術関係資料を扱う技術資料管理システムと, 公団業務に関連する技術文献を扱う技 術文献管理システムを運用している。その運用の基本は利用者自身のオンライン検索, マイク ロフィッシュおよび光ディスクを用いた一次資料の蓄積である。

[著者付与キーワード] 日本道路公団, 技術資料, 技術文献, 資料管理, オンライン検索, 電算機, 高速道路, マイクロフィッシュ，光ディスク，社内情報管理システム

[Author Abstract] Nihon Doro Kodan Laboratory has collected and contributed technical data (microfiches, aerial photographs, books and literature) on plans, desings, constructions and maintenance of the national expressways and the ordinary toll roads since 1968. This work is systematized on computer to retrieve and contribute data faster. Now Labaratory operates Technical Data Management System which manages all of technical data and Technical Document Management System which manages technical documents. These systems stand on users' on-line retrieval and data accumuration by microfiches and optical disks.

[Keywords by Author] Nihon Doro Kodan, technical data, computer, technical document, on-line retrieval, expressway, microfiche, optical disk, data management, in-house information management system

* 日本道路公団 試験所 技術情報資料課（广 194 東京都町田市忠生 1-4-1） Tel。0427(91) 1621 Nihon Doro Kodan, Laboratory, Technical Information Section

(4-1, Tadao 1 -chome, Machida-shi, Tokyo 194) 


\section{1.まえがき}

日本道路公団（以下「公団」という）では，事 業の遂行に伴って発生する各種技術関係資料を, 以後の建設や管理業務などに有効利用するため, 昭和 43 年日本道路公団試験所（以下「試験所」と いう）に技術資料センターを設けた。以来試験所 では 20 年以上にわたり，技術関係資料の収集・管 理・提供業務を行ってきている。

試験所では，これら業務で発生した報告書や図 面などの膨大な資料の検索や提供業務を迅速に行 うため，電算機を利用したシステム化を図ってい る。ここでは，試験所における技術資料の管理に ついて，その概要を紹介する。

\section{2. 公団の事業}

当公団の事業目的は，都市内高速道路を除く全 国高速道路網の建設・管理と，地方の道路公社等
以外の一般有料道路の建設・管理である。現在, 高速道路および一般有料道路を約 $5,100 \mathrm{~km}$ 供用管 理し，約 2,100 kmを建設中である(図 1 )。供用管 理延長が $5,000 \mathrm{~km}$ にも達した今, 高速道路が社会 経済に与える影響は増大し，公団技術者の業務も 社会的な責任がますます重くなってきている。

公団事業を取り巻く環境は目まぐるしく変化し ているが，あえて今の公団事業を表すとするなら ば，「横断道・都市型道路・維持管理・サービス」 がキーワードであろうか。道路建設は，日本列島 を縦断する縦貫道が概成し，これからは，交通量 が少ない割に構造物比率が高く，採算性の悪い横 断道の建設が本格化する。また最近，東京外郭環 状道路，圈央道，名古屋二環，伊勢湾岸道路，第 二京阪道など，大都市近郊での道路建設が次々に 事業化され，社会問題化している大都市の交通問 題解決に向けて歩み出したところである。

さらに，世界における日本の経済的地位が向上 するとともに，国民の生活の豊かさを求める声が

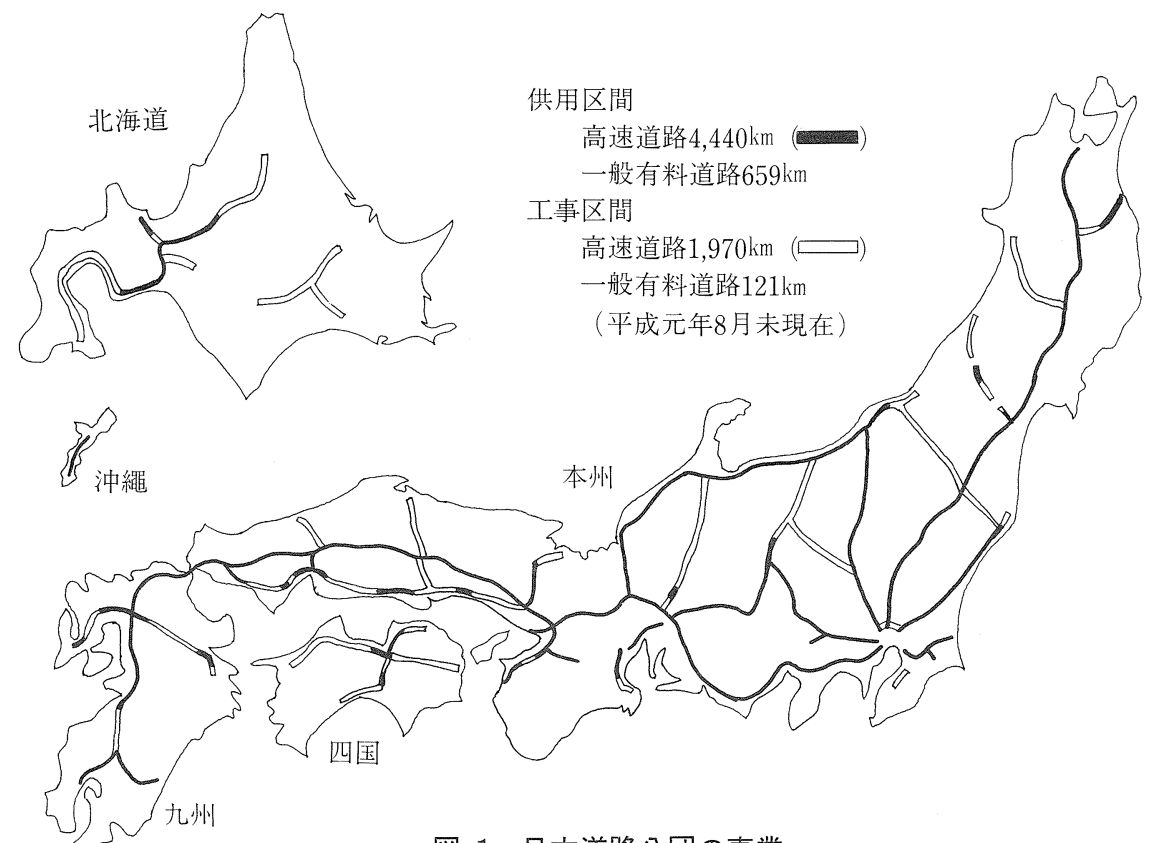

図 1 日本道路公団の事業 


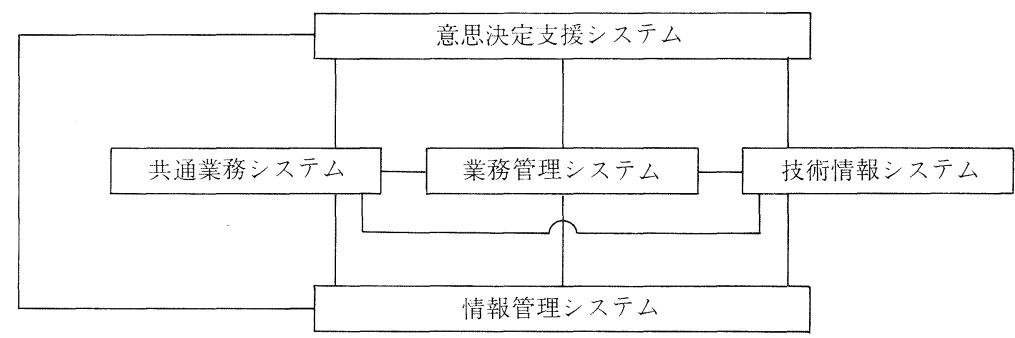

図 2 日本道路公団情報システムの基本構想

高まり，公的サービスにおいても質の高寺が求め られるようになった。当公団に関しては，特に大 都市近辺に集中する交通渋滞に対して，これまで 以上のきめ細かな対応が要求されているところで ある。

このように公団技術者の業務は，道路の計画・ 建設・管理の各段階で新たな取り組みを迫られて おり，より一層の事業の効率化，沿道環境の保全， お客様サービスの充実など，克服しなければなら ない課題は多い。

\section{3. 日本道路公団情報システム}

公団では，近年の厳しい環境の下で公団業務を 円滑かつ効率的に推進していくためには, 全社的, 長期的観点に立った事務処理の大幅な合理化，効 率化が不可欠であり，経営環境の変化に対応でき る的確かつ迅速な経営判断が可能でなければなら ないとし，(1)的確な意思決定を行うために必要な 情報の提供を正確かつ迅速に行う，(2)建設・管理 にかかる事務の迅速化，適正化を計ることを目的 として，情報システム基本構想（図 2 ）を策定し, 昭和 57 年から全社的に業務の電算化を推進して いる。

この中で技術情報システムは，全技術者を対象 とし，これまでの定常的な業務に加えて非定常的 な業務まで扱うこととしており，試験所コンピュ 一夕は，主にこの非定常的な業務を担当すること
となっている。具体的には，全社的に活用する技 術情報として資料やデー夕を収集・提供すること であり，公団が蓄積してきた技術資産を活用する ための流通基地としての役割を担うものとなって いる。

この技術情報を収集・提供することは従前から 行ってきたところであるが，全社的なシステムに 組み込まれることにより，より一層の整備，拡充 が求められている。

\section{4. 公団の技術資料管理}

\section{1 資料管理上の特徵}

当公団における技術資料とその管理には次のよ うな特徴がある11。

(1)道路構築物は一品現地生産を基本とするた め，技術資料は現場で作成され活用される。

(2)道路の維持管理のため, 50 年を越える長期間 の保存を要する。

(3)複雑多岐な自然条件・社会条件に対処するた め，統計的・経験的アプローチが主体となる。

(4)技術的判断結果の評価には長期間を要し, 資 料の確実な蓄積保存が必要である。

(5)資料はその対象位置が明確であり，この属地 性は重要項目である。

(6)資料は報告書のほか図面, 記録写真, 映画, 磁気テープなど種々の形態がある。

(7)資料は当公団外に保存されている例はまれ 
で，再入手できないものが大部分である。

(8)組織は建設部門と管理部門に別れて展開して おり，その改廃が激しく，資料の引継ぎがた びたび必要である。

(9)職員は数年おきに転勤しており，職員に依存 する情報管理・蓄積は困難である。

以上のように，当公団に扔ける資料の管理には 様々な問題があり，これを克服するには，効率的 な管理方式の確立が不可欠であった。

\section{2 技術資料管理の経緯}

公団における組織的な技術資料管理の歴史の概 略を以下述べる。

昭和 43 年 7 月：名神高速道路の建設時の資料 が分散管理されていたものを，公団全体での活用 を目的として「技術関係資料取扱要領」を制定し， 組織的な資料の収集・管理を開始した。この方式 の特徴は(1)技術関係資料の集中管理，(2)ロールフ イルムによる資料の蓄積，(3)カードセレクタによ る検索である。

昭和 53 年 7 月：資料の増加に伴って様々な問 題が生じてきた従前の方式にかえ，技術資料管理 システムの開発を進め「技術関係資料取扱要領」 もそれに沿ったものに改正した。新しいシステム の特徵は(1)マイクロフィッシュによる資料の蓄 積，(2)資料管理の電算化，(3)発注成果品の一部と してマイクロフィッシュを作成することとし，収 集蓄積の幑底化を図ったことである。

昭和 60 年 3 月：技術関係資料とは別に社内文 献を対象とした技術文献管理システムを開発し た。

昭和 61 年 4 月：公団内の本社・局・試験所のコ ンピュータを結ぶ通信ネットワークが開通した。 これより試験所では技術資料管理システムおよび 技術文献管理システムのオンライン検索サービス を開始し，代行検索から利用者自身による検索へ 移行した。

平成元年 8 月：技術文献管理システムに光ディ スクを導入し文献の自動提供を開始した。

このように試験所では現在 2 種類の資料をそれ
ぞれシステム化し，収集・管理している。すなわ ち，業務の成果品としての技術関係資料を技術資 料管理システムで，また技術文献を公団業務に関 連するものに限定し技術文献管理システムで収 集・管理している。

\section{3 一次資料の形態}

一次資料の形態は，技術資料管理システムでは マイクロフィッシュを原則とし，技術文献管理シ ステムでは光ディスクである。その使い分けには それぞれの媒体の機能の特長が現れている。マイ クロフィッシュと光ディスクを比較した場合，前 者は長期保存性に実績がある，画像品質が高い， 複製配布が便利であるなどの利点を持つが，一方 後者は高密度で記録することができる，画像編集 ができる，コンピュータ・通信ネットワークなど と結びつけ多様なシステム構築ができるなどの特 色を持つ。大まかにいってマイクロフィッシュは 保存型であり，光ディスクは活用型であるといえ よう。

技術資料管理システムでは, 資料を 50 年以上に わたり保存しなければならないため，今のところ 長期保存に実績があるマイクロフィッシュが最適 ではないかと考える。

また技術文献管理システムでは利用頻度がかな ク高いため，提供機能を重視し光ディスクを導入 したものである。なお光ディスク技術は最近のめ ざましい技術革新の中で害用化され，現在各メ一 力は競ってその機能の改良に努めている。このた め，今後ますます使いやすいものになっていくも のと思われ，これからの記録保存媒体として大き な地位を占めていく可能性が高い。

\section{5。技術資料管理システム}

このシステムは公団における調查・建設から維 持管理に至るまでの技術業務によって発生する資 料を確実に収集し，現場で必要な情報を的確に提 供することを目的とする。 


\section{1 システムの概要}

技術資料管理システムの全体の流れは図 3の通 りであり「技術関係資料取扱要領」に則って運用 されている。

技術業務の中で資料が発生すると, 調查研究報 告書，工事完成図，設計計算書等はマイクロフィ ッシュにし，その他の空中写真，磁気テープ，映 画フィルムなどはそのままの形で，技術関係資料 登録票（図4）とともに試験所へ送付され，試験 所で保存される。

保存方法として，マスタ一資料は空調設備，防 災設備の整った資料保管棟に保管される。また活 用資料のうちマイクロフィッシュは，登録番号順 に電動ファイルに配架され資料提供用に用いられ る。

資料とともに試験所に送られてくる技術関係資 料登録票の内容は，それらの資料をコンピュータ で検索するため，技術資料データベースに登録さ
れる。資料登録件数の推移は図 5 の通りである。 毎年約 3 万件の割合で増加し，現在までに約 33 万件の資料が蓄積された。資料の内訳を図 6 に示 す。全体の約半数は発注成果品であるが，これら のほとんどは調査設計業務の成果品として提出さ れる報告書, 設計計算書, 設計図などを撮影した マイクロフィッシュである。

資料の入手の手続きの基本は，まず手元の端末 から試験所のコンピュータにオンライン接続し, 資料の検索を行い必要な資料を特定する。そして 試験所に技術関係資料利用票をもって資料の提供 依頼を行うこととなっている。

\section{2 検}

索

昭和 61 年 4 月に公団内のコンピュータを結ぶ 通信ネットワークが開通したことにより，試験所 のコンピュータは全国の端末からオンラインで利 用可能となった。このため技術資料の検索は利用

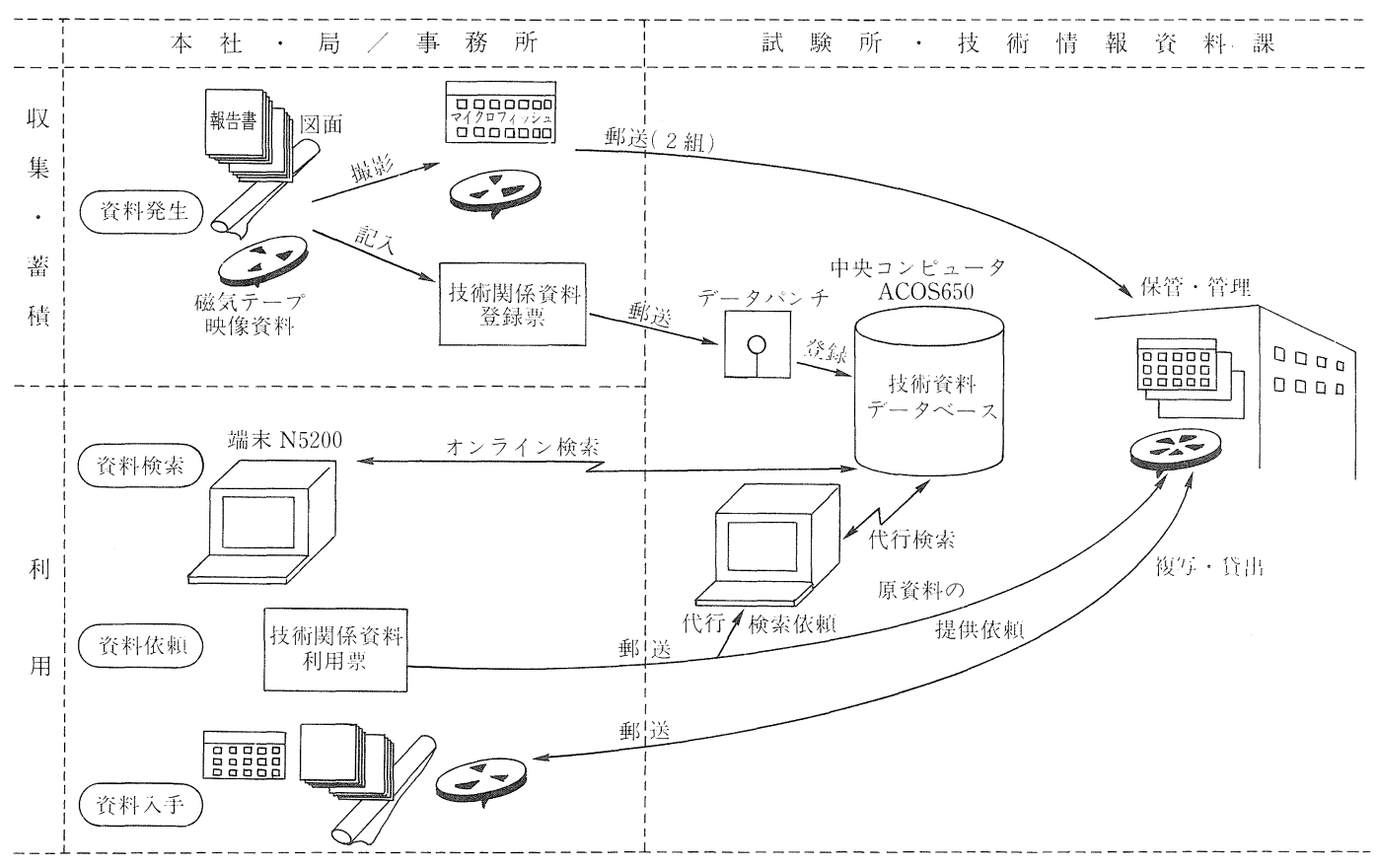

図３技術資料管理システム運用の全体概要 
情報管理 Vol. 32 No. 9 Dec. 1989

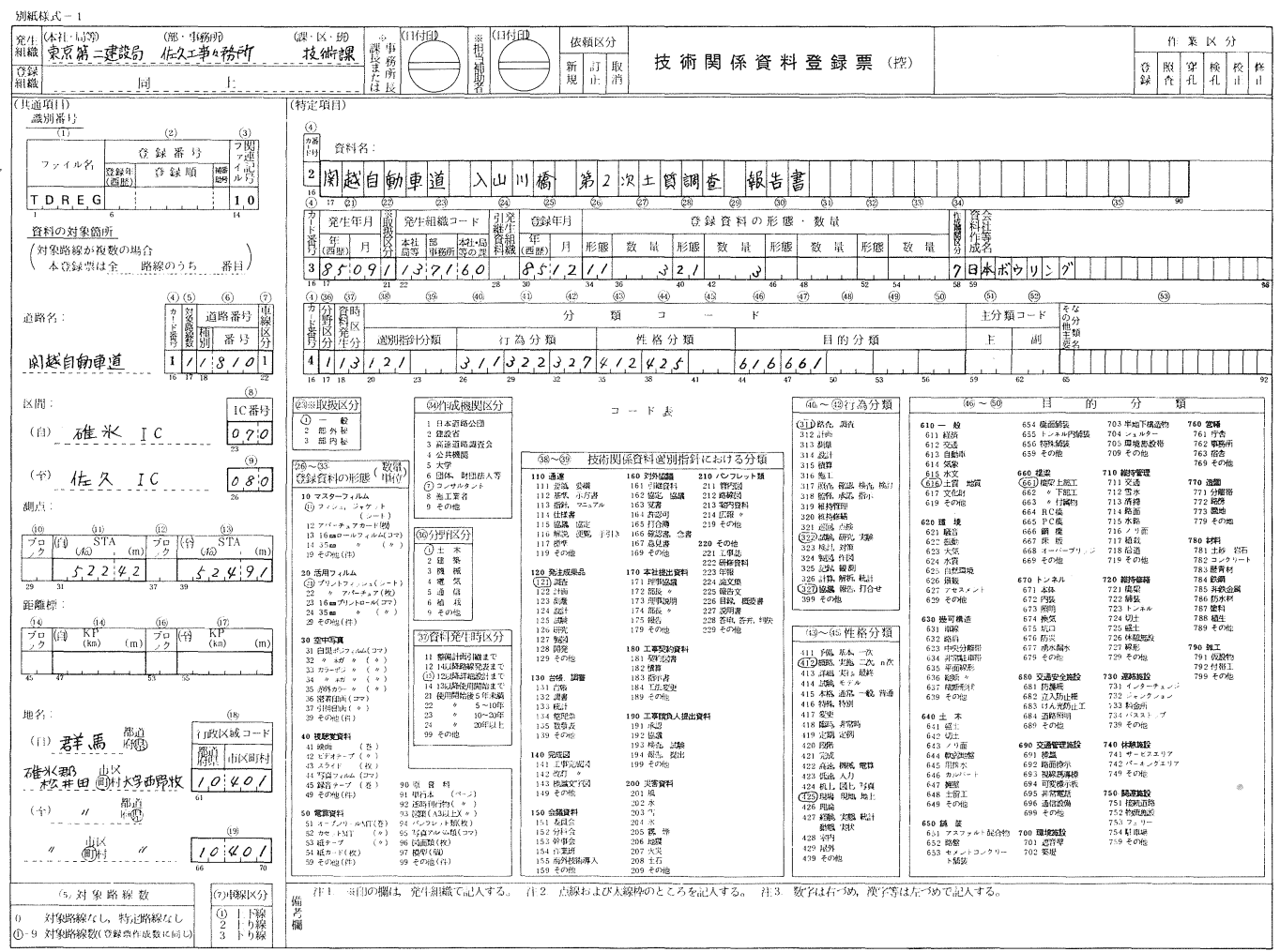

図 4 技術関係資料登録票（記入例）

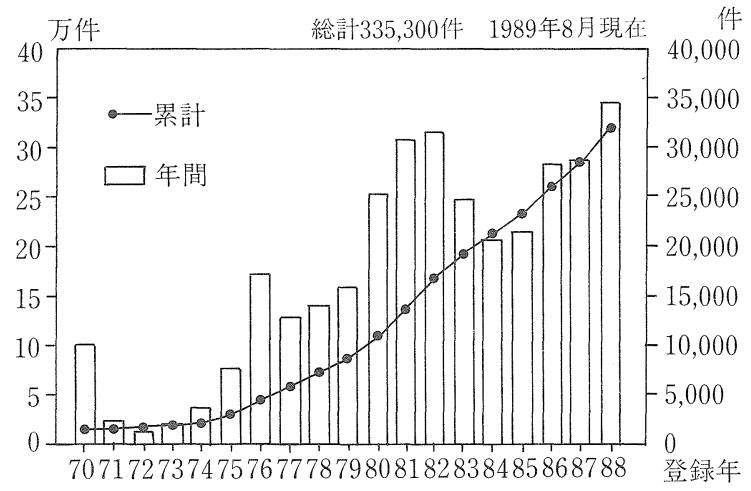

図 5技術資料の登録状況

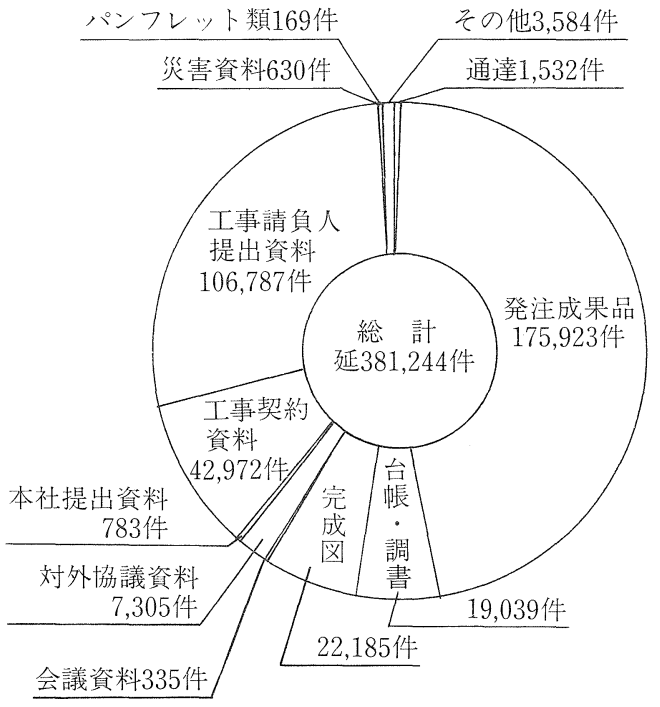

（注）分類の重出を除くと，実件数は 335,300 件である。

図 6 技術資料の分類別内訳 
者自身が職場の端末を用い，オンライン検索をす ることを基本としている。なおオンライン可能な 端末は全国の局・事務所単位に最低 1 台以上配置 されており，オンライン端末の総台数は現在約 500 台となっている。

資料の検索項目は，資料 1 件ごとに登録時に作 成される技術関係資料登録票のデー夕項目にほぼ 一致する。すなわち道路名，区間等の対象位置， 資料名，発生年月，発生組織等の書誌事項，資料 内容を表す分類名などのデー夕が検索項目とな る。

本システムは，一般技術者にとって利用しやす いものでなければならないので，手軽に検索でき るように，検索方式をある程度定型化したメニュ 一画面を用意し，平成元年 3 月から運用を行って いる。それ以前はデータベース管理システムで提 供するコマンド検索を行っていたが一般の技術者 には馴染み難いもののようであった。メニュ一画 面の場合，利用者はあらかじめ用意された入力欄 に適切なコードなどを入れればよく、コンピュー
夕に誘導されて最終的な検索ができる。検索画面 には位置コード検索画面, 内容検索画面, その他 項目検索画面の三つの画面がある。

（1）位置コード検索画面（図 7 )

道路番号と IC区間から赤象資料を絞り込む場 合に用いる。

(2) 内容検索画面 (図 8)

各種分類コード，資料名中の用語，その他分類 名などの資料内容を表す項目で検索を行うもの で，画面上の論理演算式の中にコードまたは用語 を入力する。この場合, 分類コードは完全一致検 索，資料名中の用語とその他分類名は部分一致検 索となる。

（3）その他項目検索画面（図 9)

発生組織コードや発生年月など主として書誌事 項に係わる項目で構成される。

(4) 検索結果出力（図 10)

出力様式は定型化したものを 3 タイプ用意して いる。出力は，端末画面またはプリンタに行うこ とが可能であり，出力様式・方法とも，利用者は
$\mathrm{R}$ IDLE KBO

技術資料検索シスデム
$\mathrm{A}$ ：道路番号
B ：I C 番号（自） （至）

031

位置コード㭘索画面

(道路番号は必ず入力して下さい)

（項目間梲索の条件式は全て論理積（※）検索で行います。）

検索対象となる一時ファイルのファイル番号を入力して下さい。 (全孛一夕を対象とする場合は需です。)

次の番号を選択して下さい。

1. 検索を行う

2 . 初期画面浽房す

図 7 位置コード検索画面 


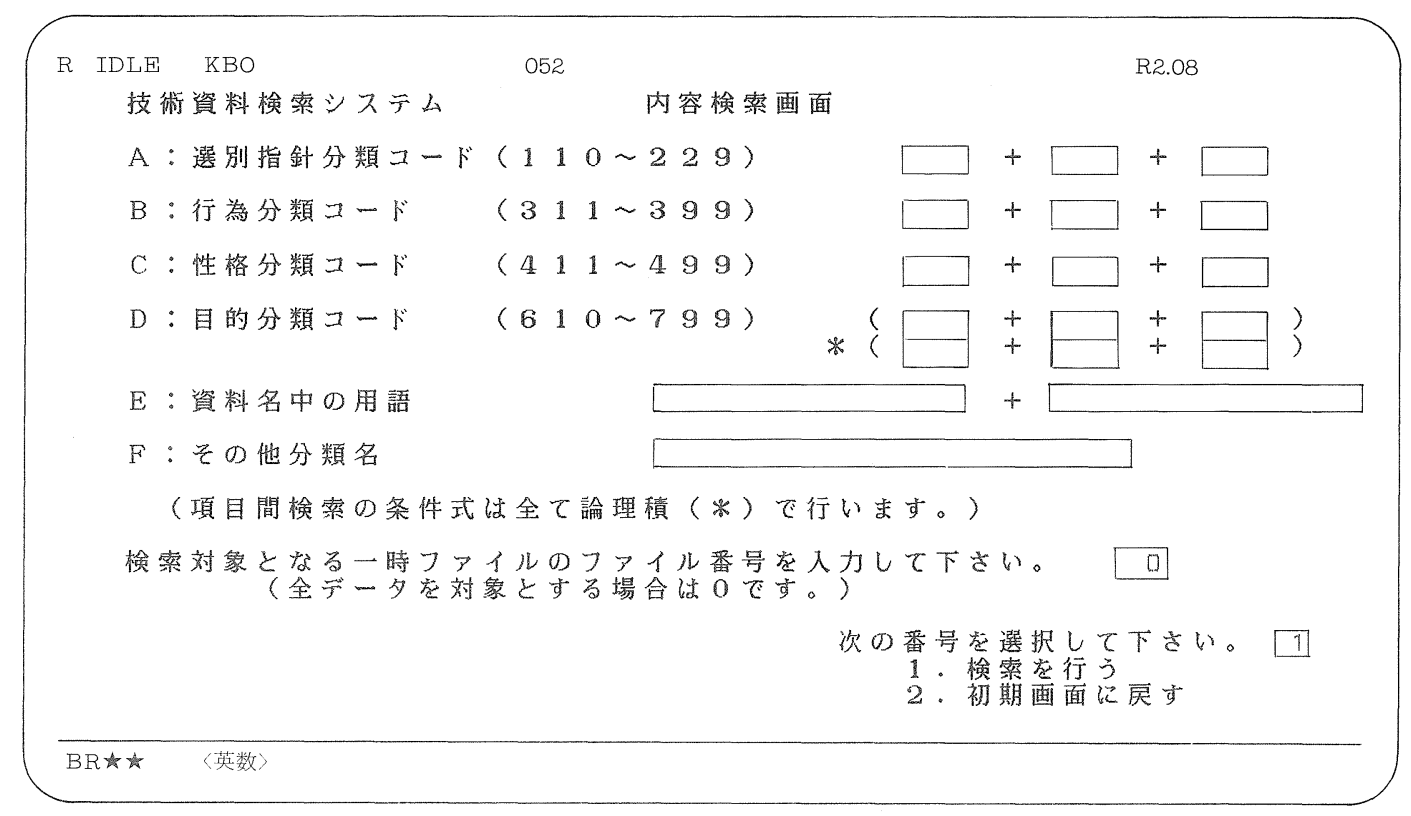

図 8 内容検索画面

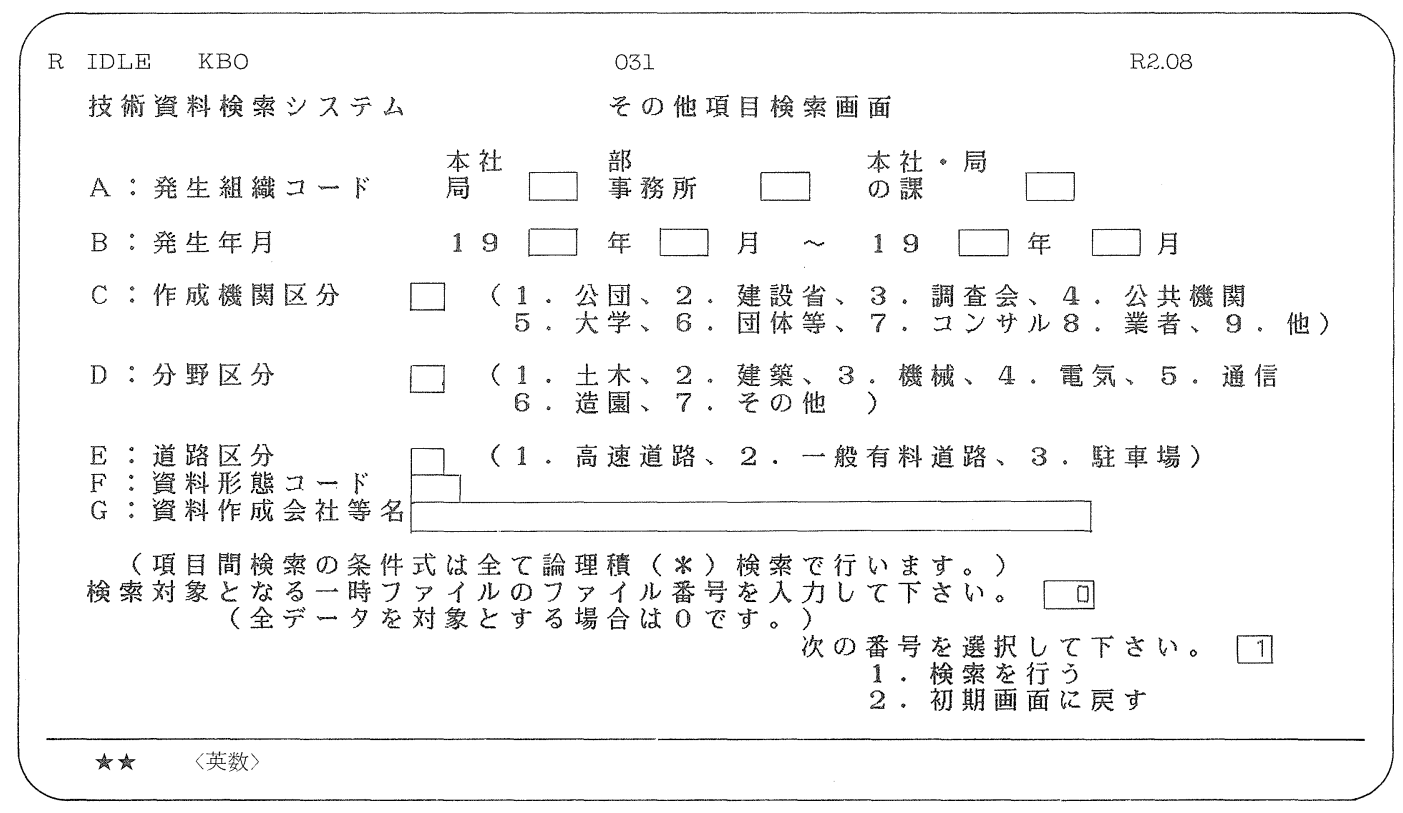

図 9 その他項目検索画面 


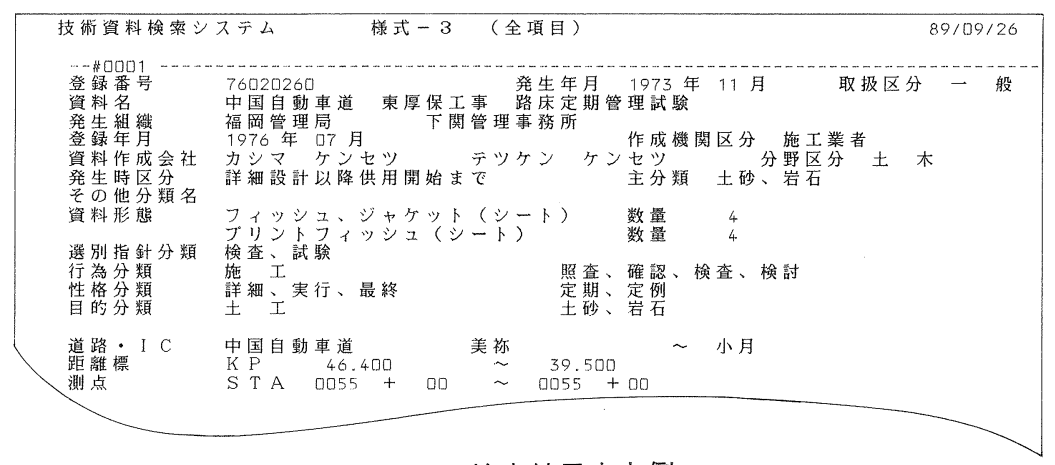

図 10 検索結果出力例

端末画面から選ぶことができる。

\section{3 利用}

\section{3. 1 利用方法}

利用者は，検索により必要な資料の登録番号を 知ることができれば，試験所に資料提供の依頼を して資料を入手することができる。資料提供の方 法として，次のようなものがある。

（1）マイクロフィッシュの場合

現在ほとんどの部署にはマイクロフィッシュを 拡大コピーできるリーダプリンタがないのが実状 であり，試験所で拡大コピーして複写紙を提供し ている場合が多い。利用者のところにリーダプリ ンタがあれば，試験所で複製フィルムを作成し利 用者へ送付することが可能となり，資料提供の効 率化，迅速化を図ることができる。

（2）空中写真の場合

空中写真の密着または引伸アルバムからカラー コピーをとるか，ネガフィルムから密着または引 伸印画を作成し提供する。

(3) 磁気テープやビデオテープの場合 期間を定めて貸出す。

\section{3. 2 利 用 状 況}

資料の提供件数はここ数年, 年間 1,000 件から 1,500 件の間を推移している。昭和 63 年度は約 1,200 件の利用があった。ただし今年になってか
ら検索方式をメニュー化したのに伴い，㭘索利用 回数が著しい伸びを見せており，それに比例して 資料の提供件数も増加する傾向にある。

\section{6. 技術文献管理システム}

科学技術の進歩の成果は一般に技術文献として 発表されるので，技術業務を遂行する上で，これ らを適時入手し活用することが不可欠である。土 木事業に打いては一品現地生産方式を基本とする ため，各種の参考事例が重要になるほか，長年に わたり維持補修を要するため, 個々の過去の経緯 をコンパクトにまとめた文献が有用である。

\section{1 システムの概要}

技術文献は全社的にあらゆる技術業務に利用さ れることから，公団では試験所の中央システムに データベースを構築し, 昭和 61 年 4 月から技術文 献管理システムの運用を行っている。(図 11)。

公団職員が文献を執筆すると，執筆者自身にそ の文献の索引を文献抄録記入票 (図 12)に書いて もらい，試験所に集める。試験所ではそれを技術 文献データベースに登録し，文献の検索が全国の オンライン端末で可能となる。

さらに本システムの機能の特徵として，検索の みならず，文献の原文提供もシステム機器による 


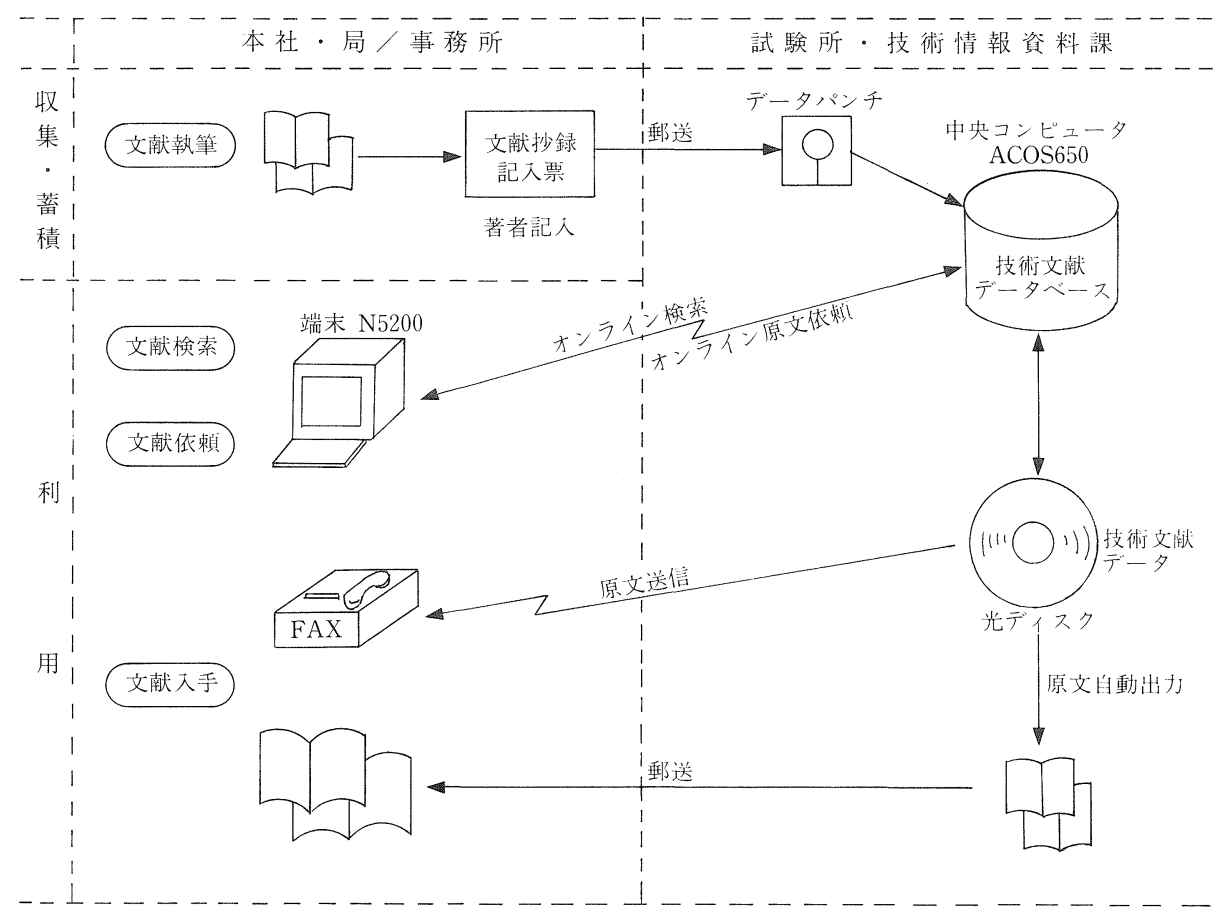

図 11 技術文献管理システム運用の全体概要

自動化を図っている2)。これは登録文献のすべて を事前に光ディスクに入力しておき，利用者のオ ンライン端末からの依頼に応じ，自動的に相手方 のファクシミリに出力させるものである。また利 用者は郵送も希望でき，その場合文献は光ディス クからリスト付きの送り状とともに自動出力さ れ，係のものが郵送の手続きをとる。

蓄積の対象とする文献は，公団業務に密接に関 連するものに限定することとし, 図 13 に示すよう に, 社内刊行物, 研究成果品, 投稿文献等を現在 約 11,000 件収集・蓄積している。また最近では新 たな文献が毎年約 800 件程度発生している。

\section{2 検}

\section{索}

文献の検索項目は文献抄録記入票のデー夕項目 に一致する。すなわち道路名, 区間等の対象位置,

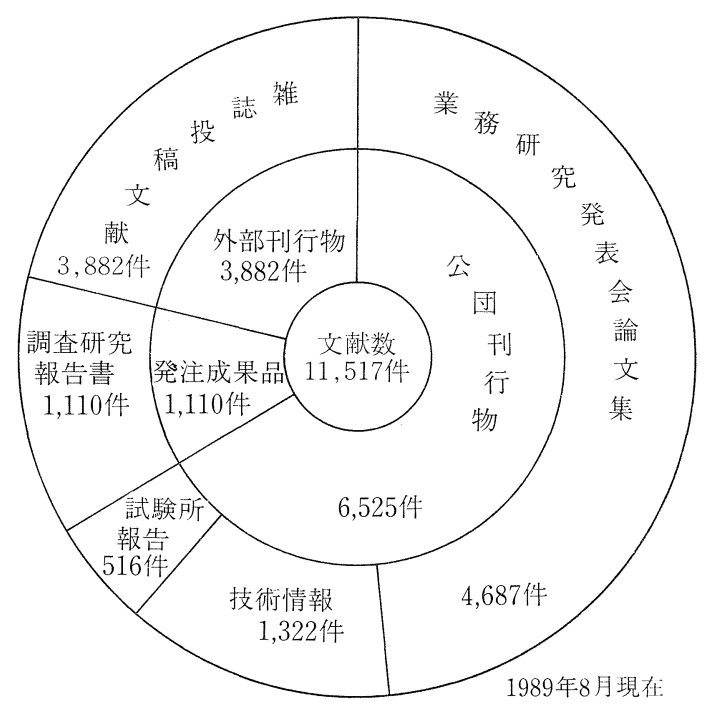

図 13 技術文献の収録内容 
(記入例)

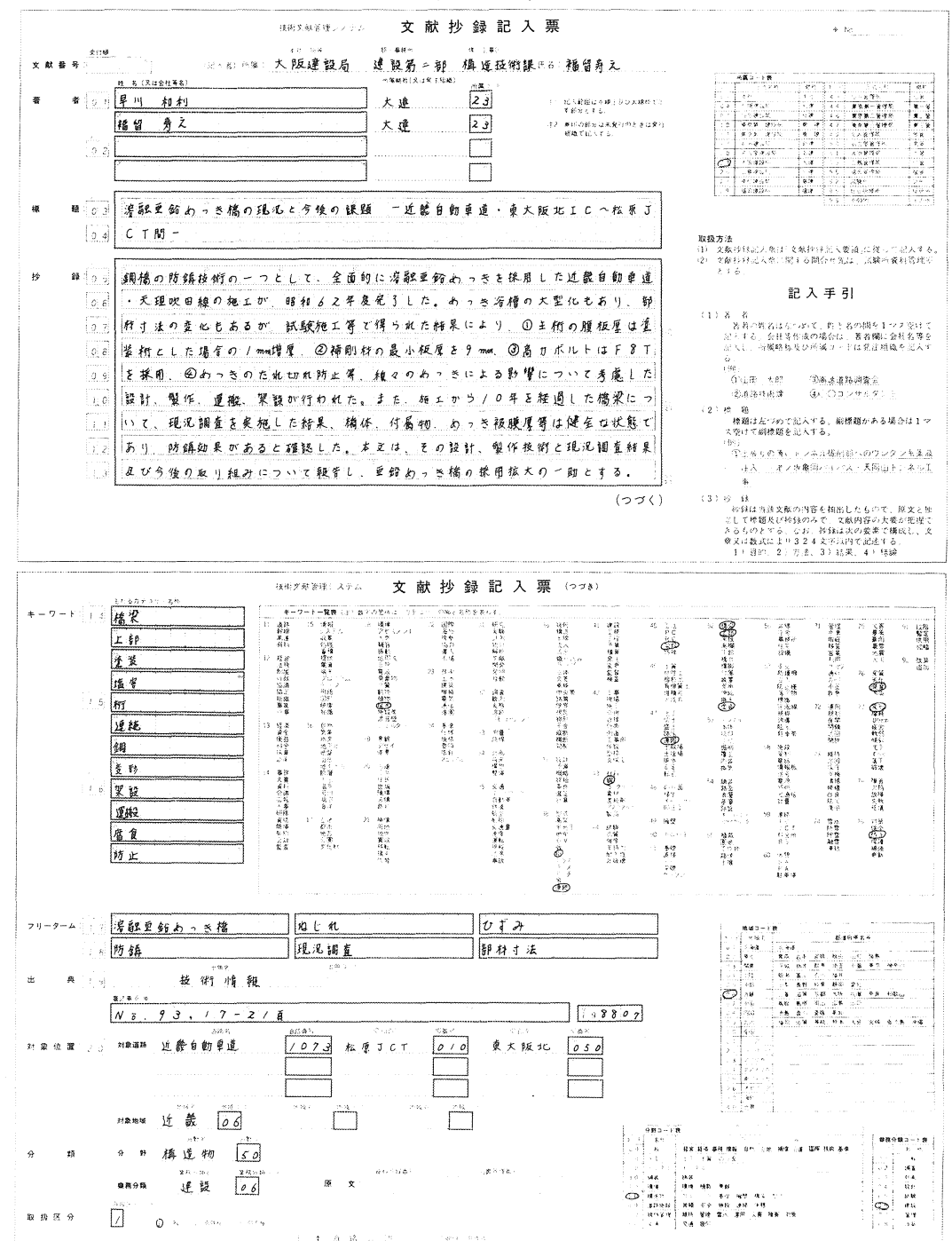

図 12 文献抄録記入票

文献名, 発生年月, 発生組織等の書誌事項, 文献 内容を表すキーワードなどのデー夕が検索項目と なる。

キーワードは公団の技術業務全般を表す統制語 として 385 語定めている。このキーワードの特徴
としては，一般技術者を利用対象者としているた めキーワードの総数を比較的少なくしているこ と，またキーワードの組み合わせで多様な概念が 表せるように個々のキーワードは短単位型として いることなどである゙๋。 
当システムも技術資料検索システムと同様に， 一般技術者が随時利用するものであるため，初心 者でも容易に使えるようにメニュ一画面による検 索を基本としている。検索項目に対応し，内容検 索画面，その他項目検索画面の二つの検索画面を 設けている。

(1) 内容検索画面 (図 14)

キーワード，フリーターム，標題中の用語など の文献内容を表す項目で検索する場合に用いる。 画面上の論理演算式の中にキーワードまたは用語 を大力する。この場合キーワードは完全一致検索, フリータームおよび標題中の用語は部分一致検索 となる。

（2）その他項目検索画面(図 15)

著者名，所属コード，出典コード，道路番号等 で検索することができる。

(3) 検索結果出力 (図 16)

出力様式は定型化したものを 4 タイプ用意して いる。出力は, 端末画面またはプリンタに行うこ
とが可能である。

\section{3 原文の自動提供}

光ディスクを用いた文献の原文提供の自動化 は，平成元年 8 月から運用を開始した。それ以前 は文献を入手するためには，技術関係資料利用票 をもって，別途試験所に複写または貸出の依頼を しなければならなかった。この場合利用者にとっ て迅速な文献入手ができず，また利用票を作成し なければならない煩わしさがあった。

このような問題を克服するために，原文提供の 自動化を図ったが，その利点としては次の 4 点等 があげられる。

(1)利用者はオンライン端末画面から直接原文依 頼ができ，依頼が手軽になった。

(2)利用者は手元のファクシミリから自動的に, また比較的短時間で原文を入手できるように なった。

(3)システム運用者は個別の複写要求に応じるこ

$\begin{array}{llll}R & \text { IDLE } & \text { KBO } & \text { R21 }\end{array}$

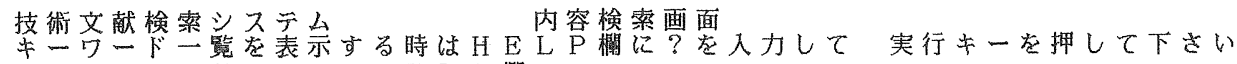

A:キーワード
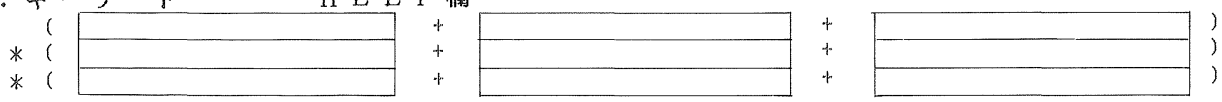

$\mathrm{B}:$ フリーターム
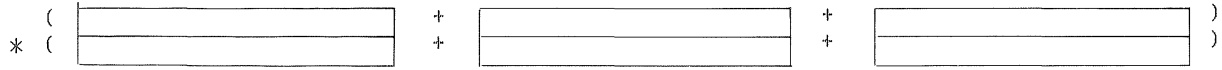

C : 標題中の用語
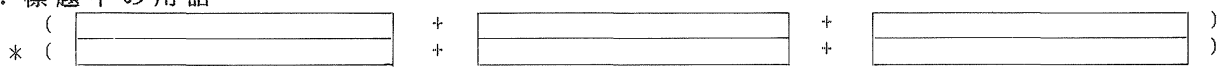

項目間検索の条件式を入力して下さい。算子; $(+)$ 和, (

検索対象となるファイルのファイル番号を人力して下さい。可

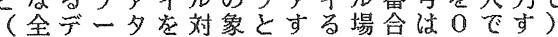

次の番号を選択して下さい。

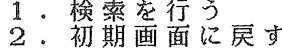

$\mathrm{RB} \star \quad[$ かな $]$

図 14 内容検索画面 
$R$ IDLE KBO

技術文献検索システム学の他項目検索画面

コ一ド表表示したい時はH E L P 欄に”?”を入力して実行キ一を押して下さい。

$\mathrm{A}$ ：著者名

B : 所属コード

$\mathrm{C}:$ 出典コード

D : 発行年月

$\mathrm{E}$ : 道路区分

$\mathrm{F}$ : 道路番号

I C 番号 (自) 〜 (至)

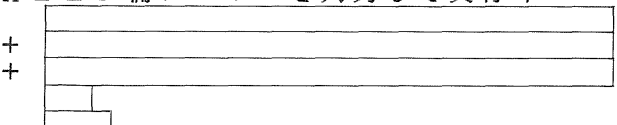

: 地域 $\geq-$

$\mathrm{H}$ : 分野コード

I: 業務分類コード

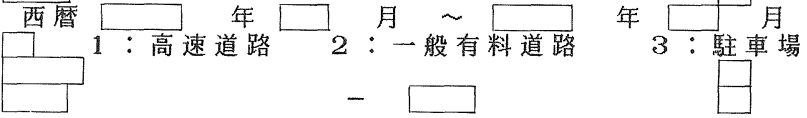

（項目間検索の条件式は全て論理䅡（*）検索で行います。）

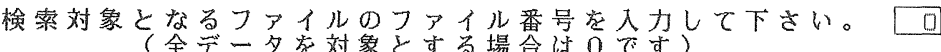
次の番号を選択して下さい。

1. 検索を行う

2 . 初期画面飞戻す

図 15 その他項目検索画面

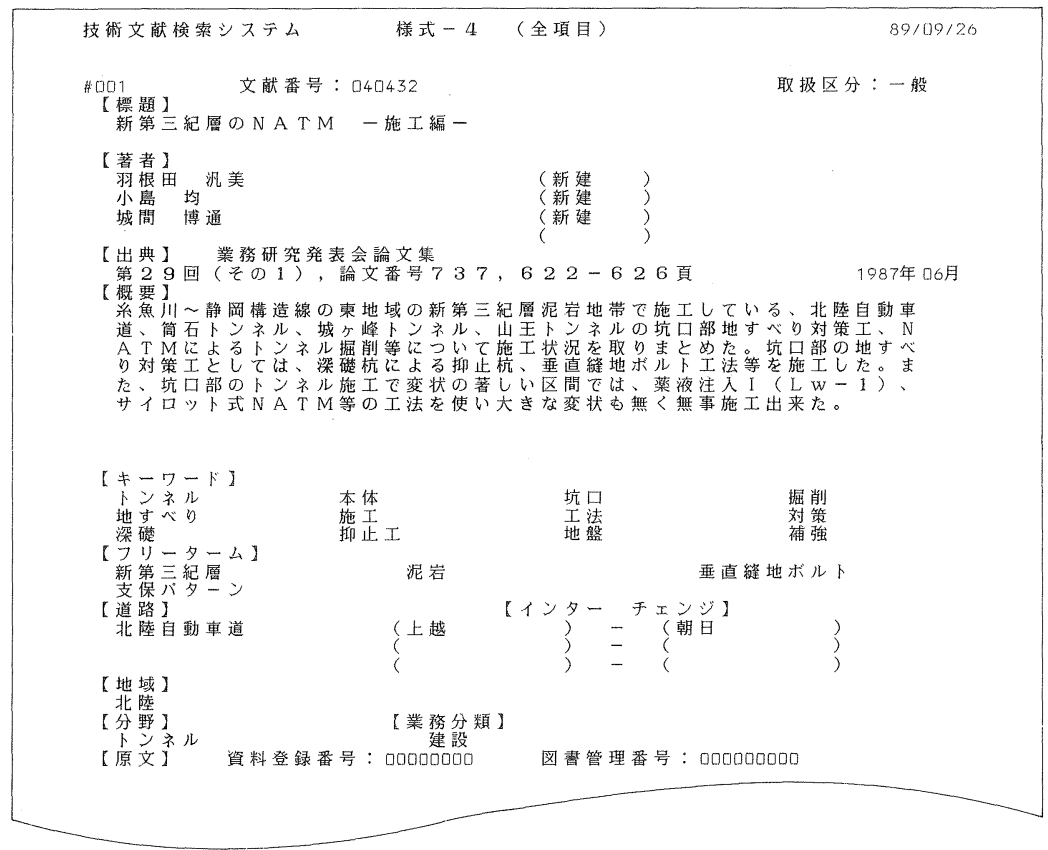

図 16 検索結果出力例 
$R$ IDLE KBO

技術文献検索システム
045

原文依頼画面

$\mathrm{A}$ ：原文出力方法を選択して下さい。

1. F A X , 2。郵送

B：FAXの回線区分を選択して下さい。

1. N T T , 2 。業務用電話

C : F A X の時は、F A X 直結の電話番号を人力して下さい。

$$
\text { 例 } 0427913717 \text { ( N T T ), } 835999 \text { (業務用電話) }
$$

$\mathrm{D} ： \mathrm{FAX}$ 又 又郵送のあて先名を入力して下さい。

氏名（漢字）

所属（事務所。課名等）

$\mathrm{E}$ ・文献番号（例 018365 ）

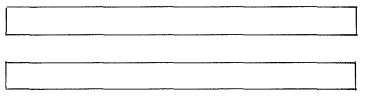

(最大 5 件まで)
例高速太郎

例 東一管 横浜（管）

6 件以上の場合は再依頼して下さ心。

次の番号を人力して下さい。

1・原文を出力する

2 - 初期画面に戻导

図 17 原文依頼画面

R IDLE KBD

技術文献検案システム

依頼日時依頼者名

8907051640 畔田雅裕

8907051638 畔田雅裕

8907051637 畔田雅裕

8907051635 畔田雅裕

8907041320 西陽

8907041319 宮坂芳治

8907041318 見方 功

8907041317 弦間

8907041317 加菻

8907041317 本松資朗
075

原文送付状況問合せ画面

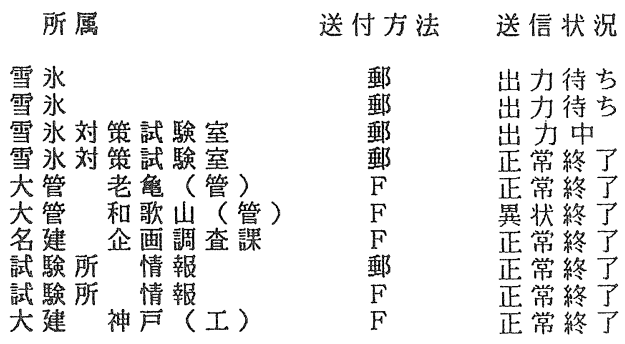

次の番号を入力して下さい。

2. 初期画面飞戻す 
となく，あらかじめ一括して原文を大力する ため, 複写・提供業務の効率化を図ることが できる。

(4)光ディスクに入力すれば文献の管理・保管が 厳密にでき，その污損・紛失をふせぐことが できる。

（1）原文依頼画面 (図 17)

入手したい文献がわかると, 原文依頼画面から その提供依頼を行う。所定の欄に, 出力方法, フ アクシミリの回線区分および電話番号, 宛先の所 属および氏名の略称，そして必要とする文献番号 を最大 5 件まで入力する。

（2）原文送付状況問合女画面(図 18)

依頼文献の到着が遅い場合, 原文送付状況問合 せ画面によって処理状況が確認できる。処理状況 に応じて「処理中」,「出力待ち」,「正常終了」,「異 状終了」のメッセージが用意されている。

\section{4 利 用 状 況}

文献の提供件数は年を追うごとに増加してお $\eta$, 昭和 63 年度は約 500 件の利用があった。これ はシステム運用以来行ってきた検索方法の改良お よび利用のPRによるところが大きい。また光デ イスクによる自動提供を開始した後, 提供件数は 著しく増加する傾向にある。

\section{7. 今後の課 題}

今後の技術資料管理上の課題を資料の収集・蓄 積, 利用に分けて述べる。

\section{1 資料・文献の収篗・蓄積}

（1）現在,技術資料の登録基準は一部曖昧な点が あり，資料作成部署ごとに登録資料の範囲が一部 違っている。必要な資料の登録漏れを防ぐため, 作成すべき資料種別を規定に明確化する必要があ る。

（2）資料の利用の観点から報告書等の記述形式 の統一を図る必要がある。

（3）公団の技術資料はその封象位置が明確であ
ク，属地性が重要であるにもかかわらず，事業の 各段階で位置表示が異なるため，資料に付けられ る位置情報は，それぞれ異なる。沉用的な検索を 行うには絶対位置情報を持つことが不可欠であ ク，今後その整備を図っていく必要がある。

（4）特に文献など情報の新鮮さを求められるも のは, 発生したら即時登録するシステム化を目指 す必要がある。

\section{2 資料・文献の利用}

（1）技術資料管理システムは技術関係の種々の 資料が登録されているが, 検索効率を上げるため, 資料種別ごとのデータべースを追加する必要があ る。

（2）不特定多数の一般技術者の利用を基本とし ているため, 検索の徹底した簡易化を図る必要が ある。当面，コード表の画面表示，へルプ機能の 充実など，端末操作をより一層簡単化するが，長 期的には AIの導大により検索キーについての統 制をゆるくし、フリータームを主体とする操作説 明書の不要な検索方法を目指す。

（3）技術資料は，現在，試験所でマイクロフィッ シュを複写して提供している場合がほとんどであ るため，資料の提供に時間がかかっている。資料 提供の迅速化を図るため, 複製フィッシュでの提 供をもっと進めることを基本に，今後利用者側へ のリーダプリンタの配備を鋭意進めていかなけれ ばならない。また利用頻度の高い一部の資料につ いては, 光ディスクへの入力など検討する必要が ある。

（4）技術資料管理システムにおいて, 試験所への 資料依頼が簡易に行えるよう，その手続きの簡素 化を図る必要がある。このため, 現在, 資料の依 頼は技術関係資料利用票で行っているが，技術文 献と同じようにオンライン端末から直接依頼が行 えるようにしていきたい。

\section{8.あとがき}

公団の技術資料の管理についてその概要を述べ 
てきた。現在，オンライン検索も徐々に一般技術 者に定着しつつあり，資料の提供件数も増加の傾 向をみせている。資料の管理もいよいよ保存主体 から，本格的な利用の時代の緒についたのかもし れない。これは情報処理機器の発達によるところ が大きいが，最終的に問われるのは依然として情
報の質と量である。良質の資料をよく利用しても らうことを基本に，今後とも資料の管理方式につ いては改善をはかっていきたい。

この報告について読者の方々のご意見，ご批判 をお願いしたい。

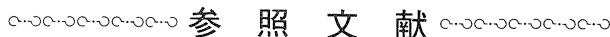

1）兼田郁，山崎正勝，古川健．日本道路公団におけ る技術資料システムの開発。情報管理。24（1）5770 (1981)

2）花田潤一，弦間和博。光ディスクを利用した技術 文献サービス。平成元年度関東建設技術研究発表会
論文集。140-143(1989)

3）兼田郁, 花田潤一, 加藤潔。社内技術文献管理シ ステムに扔ける検索用語の分析と新キーワードの 作成·評価。第 25 回情報科学技術研究集会発表論文 集. 139-154 (1989) 